\title{
CORROSION RESISTANCE IMPROVEMENT OF AISI 316L STAINLESS STEEL USING NITROGEN ION IMPLANTATION
}

\section{PENINGKATAN KETAHANAN KOROSI AISI 316L STAINLESS STEEL MENGGUNAKAN IMPLANTASI ION NITROGEN}

\author{
Sudjatmoko, Lely Susita R.M., Wirjoadi, Bambang Siswanto \\ Center for Technology of Accelerator and Material Process, BATAN \\ Jl. Babarsari P.O. Box 6101 Ykbb, Yogyakarta 55281 \\ e-mail: djatmoko@batan.go.id
}

Received 03 April 2013, received in revised form 24 April 2013, accepted 25 April 2013

\begin{abstract}
CORROSION RESISTANCE IMPROVEMENT OF AISI 316L STAINLESS STEEL USING NITROGEN ION IMPLANTATION. The nitrogen ion implantation can be used to improve surface mechanical properties and corrosion resistance behavior of AISI 316L stainless steels by modifying the near-surface layers of these materials. In this study, an AISI 316L stainless steel plate was implanted with the optimum ion dose of $5 x$ $10^{16} \mathrm{ion} / \mathrm{cm}^{2}$ for ion energy variation of 60,80 and $100 \mathrm{keV}$. Microhardness was measured by Vickers method, and the results of measurements clearly indicate an enhancement hardness behavior for nitrogen implanted layer. It is found that the implanted layer hardness was increased by a factor of 1.3 in comparison to that of the unimplanted samples. The increased hardness resulting from nitrogen ion implantation was attributed to the formation of an iron nitride phase. Microstructure, chemical composition and surface morphology studied using the technique of Scanning Electron Microscope (SEM) coupled with Energy Dispersive X-ray (EDX) and X-ray Diffraction (XRD). Analysis of SEM-EDX micrographs and XRD diffraction patterns indicate that the nitrogen implanted layer is composed of a metastable single phase which has properties very hard, good corrosion resistance behavior and wear resistance surface layers of stainless steel components. Effects of nitrogen ion implantation on the corrosion properties of AISI 316L stainless steels was evaluated using potentiostat PGS 201T. Corrosion properties of test results showed that there was a significant improvement in the corrosion resistance in the case of nitrogen implanted samples.
\end{abstract}

Keywords: AISI 316L stainless steel, corrosion resistance, nitrogen ion implantation, microhardness, wear resistance

\section{ABSTRAK}

PENINGKATAN KETAHANAN KOROSI AISI 316L STAINLESS STEEL MENGGUNAKAN IMPLANTASI ION NITROGEN. Implantasi ion nitrogen dapat digunakan untuk meningkatkan sifat mekanik permukaan dan sifat ketahanan korosi stainless steel AISI 316L dengan memodifikasi lapisan dekat-permukaan bahan tersebut. Dalam kajian ini, plat stainless steel AISI 316L diimplantasi dengan dosis ion optimum $5 \times 10^{16}$ ion/ $\mathrm{cm}^{2}$ untuk variasi energi ion 60, 80 dan $100 \mathrm{keV}$. Kekerasan mikro diukur menggunakan metode Vickers, dan hasil pengukuran jelas menunjukkan peningkatan sifat kekerasan dari lapisan yang terimplantasi nitrogen. Dari pengukuran diperoleh bahwa kekerasan lapisan yang terimplantasi meningkat dengan faktor 1,3 dibandingkan dengan cuplikan yang tidak diimplantasi. Peningkatan kekerasan akibat implantasi ion nitrogen ini disebabkan oleh pembentukan fasa nitrida besi. Struktur mikro, komposisi kimia dan morfologi permukaan dipelajari menggunakan teknik Mikroskop Elektron Scanning (SEM) yang dilengkapi dengan energi dispersif sinar-X (EDX) dan Difraksi Sinar-X (XRD). Analisis mikrograf SEM-EDX dan pola difraksi $X R D$ menunjukkan bahwa lapisan yang terimplantasi nitrogen terdiri dari fasa tunggal metastabil yang memiliki sifat sangat keras, sifat ketahanan korosi yang baik dan tahan aus pada lapisan permukaan komponen-komponen stainless steel. Pengaruh implantasi ion nitrogen pada sifat korosi AISI 316L stainless steel dievaluasi menggunakan potensiostat PGS 201T. Hasil uji sifat korosi menunjukkan bahwa terjadi peningkatan ketahanan korosi yang signifikan pada cuplikan yang terimplantasi nitrogen.

Kata kunci: stainless steel AISI 316L, ketahanan korosi, implantasi ion nitrogen, kekerasan mikro, ketahanan aus 
Jurnal Iptek Nuklir Ganendra

Ganendra Journal of Nuclear Science and Technology

Vol. 16 No. 2 Juli 2013: 67-75

\section{INTRODUCTION}

$A_{0}^{u}$ ustenitic stainless steels are generally used where excellent corrosion resistance and good mechanical performance are required, and for this reason are widely used in many industrial domains, such as in food and chemical processing, marine and petrochemical, and especially in biomedical industries ${ }^{(1-3)}$. The application of austenitic stainless steel as an orthopedic implant material not only requires high corrosion resistance and good formability but also excellent wear behavior within a corrosive environment such as body fluids ${ }^{(4)}$.

There are three categories of materials presently used in prosthetic devices: metals, polymers and ceramics. Biometals used in orthopedic implants include surgical grade stainless steel, cobalt-chromium alloys, titanium and titanium alloys. Austenitic stainless steels, especially AISI 316L stainless steel has been used as a material for surgical implant applications for many years and is still an inexpensive alternative to currently used implants made from titanium and its alloys and to cobalt-based alloys ${ }^{(5)}$. AISI $316 \mathrm{~L}$ stainless steel is being widely used in artificial knee and hip joints as well as internal fixation devices in biomedical applications. More specifically, 316L stainless steel is used in the medical field as an implant material due its unique property of good corrosion resistance and biocompatibility ${ }^{(6)}$. However, it has been reported that $316 \mathrm{~L}$ stainless steel orthopedic implants corrode in body environment and release iron, chromium and nickel ions ${ }^{(4,7-8)}$. Significant quantities of iron ions released to the neighboring tissues may pose risks of local tumors and mechanical failure of the implant ${ }^{(9)}$. Chromium and nickel are known carcinogens, and they are not only found in the tissues surrounding the implant, but also in blood and urine samples, often at levels higher than in individuals professionally exposed to these metals.

Austenitic stainless steels are well known for their good corrosion resistance, but the friction and wear properties of these materials can present problems for biomedical use. Although implant devices such as bone plate and artificial hip joint made of $316 \mathrm{~L}$ stainless steel shows extremely good corrosion resistance, it is sometimes fractured in human body with corrosion, fretting fatigue and so on. Wear and corrosion resistance improvement of $316 \mathrm{~L}$ stainless steel can often be accomplished by an appropriate surface modification technique $(6,10)$. There are many techniques such as ion implantation, physical vapor deposition, ion nitriding, laser surface treatment, etc. have been utilized to improve the wear and corrosion resistance of $316 \mathrm{~L}$ stainless steel ${ }^{(11-13)}$. Ion implantation is a surface treatment mainly used in industry for improving the wear resistance of metals. In the field of biomaterials, nitrogen ions are implanted into austenitic stainless steels ${ }^{(10,11)}$ and titanium alloys such as Ti-6Al$4 \mathrm{~V}^{(14)}$ to improve the wear resistance, compatibility and the corrosion resistance.

In this study, we investigate the influence of nitrogen ion implantation on the formation of the nitride layer on AISI 316L stainless steel alloy. The hardness behavior and the corrosion resistance of the nitrogen implanted layer will also be investigated. The hardness of the unimplanted and implanted samples was studied using Vickers microhardness tester, and the surface microstructures, chemical composition and morphologies of the unimplanted and implanted samples were studied with SEM-EDX and XRD respectively.

\section{METHODOLOGY}

The AISI 316L stainless steel was used as the metal substrate with the elemental composition (wt.\%) of $69 \% \mathrm{Fe}, 18 \% \mathrm{Cr}, 10 \% \mathrm{Ni}$ and $3 \% \mathrm{Mo}$. AISI $316 \mathrm{~L}$ stainless steel samples of the $10 \times 10 \times 2 \mathrm{~mm}$ size polished using abrasive papers 800 up to 1,200 mesh, and finally polishing was done using diamond paste and velvet fabric in order to produce scratch-free mirror-finish surface. The polished specimens were washed with detergent solution and further cleaned with alcohol and acetone using ultrasonic cleaner.

Nitrogen ion implantation of samples performed using ion implanter of Centre for Technology of Accelerator and Material Process - BATAN, Yogyakarta. The ion implanter system can generate gas ions and accelerate it up to the maximum ion energy of $150 \mathrm{keV}$. In this study different nitrogen ion energy in the range of 60,80 and $100 \mathrm{keV}$ with optimum ion dose of $5 \times 10^{16} \mathrm{ion} / \mathrm{cm}^{2}$ have been carried out.

Measurement of microhardness profile of the samples was carried out by using Vickers microhardness tester. Microstructure and chemical composition of the samples examined using the analytical techniques of scanning electron microscopy (SEM) equipped with energy dispersive $\mathrm{x}$-ray (EDX). X-ray diffraction analysis (Cu$\mathrm{K} \alpha$ radiation) was performed in order to identify the phases present in the surface layers. Corrosion resistance 
was measured in simulated body fluids, namely Hank's solution, using potentiostat PGS 201T. The solution was prepared with distilled water and reagent grade chemicals, and the tests were carried out at room temperature. The chemical composition of Hank's solution is comprised of $\mathrm{NaCl}-8.0, \mathrm{CaCl}_{2}-0.14, \mathrm{KCl}-0.40, \mathrm{NaHCO}_{3}-0.35$, Glucose-1.00, $\mathrm{NaH}_{2} \mathrm{PO}_{4}-0.10, \mathrm{MgCl}_{2} .6 \mathrm{H}_{2} \mathrm{O}-0.10, \mathrm{Na}_{2} \mathrm{HPO}_{4} .2 \mathrm{H}_{2} \mathrm{O}-0.06, \mathrm{MgSO}_{4} .7 \mathrm{H}_{2} \mathrm{O}-0.06 \mathrm{~g} / \mathrm{L}$ respectively ${ }^{(15)}$.

\section{RESULTS AND DISCUSSION}

Graph hardness of the implanted samples are shown in Figure 1. From this figure it can be seen that the optimum hardness of the implanted AISI 316L SS samples is about $510 \mathrm{Hv}$ and obtained at an ion energy of 80 $\mathrm{keV}$. Compared to the unimplanted samples, the hardness of the implanted samples is higher than that of the unimplanted sample by a factor of 1.3. Enhanced hardness behavior observed here is mainly attributed to the formation of nitride layer on the surface of samples. Similar results are also obtained by Ozturk ${ }^{(10)}$ who has done the nitrogen ion implantation with a dose of $1 \times 10^{18} \mathrm{ion} / \mathrm{cm}^{2}$ and ion energy of $85 \mathrm{keV}$ on the surface of AISI $316 \mathrm{~L}$ stainless steel. The hardness for the implanted layer is higher than that of the substrate by a factor of 1.6 . Literature studies indicate that due to the formation of nitride precipitates, the implanted layer becomes very hard ${ }^{(10,16)}$. Also, the increased hardness resulting from nitrogen implantation may be due to stresses.

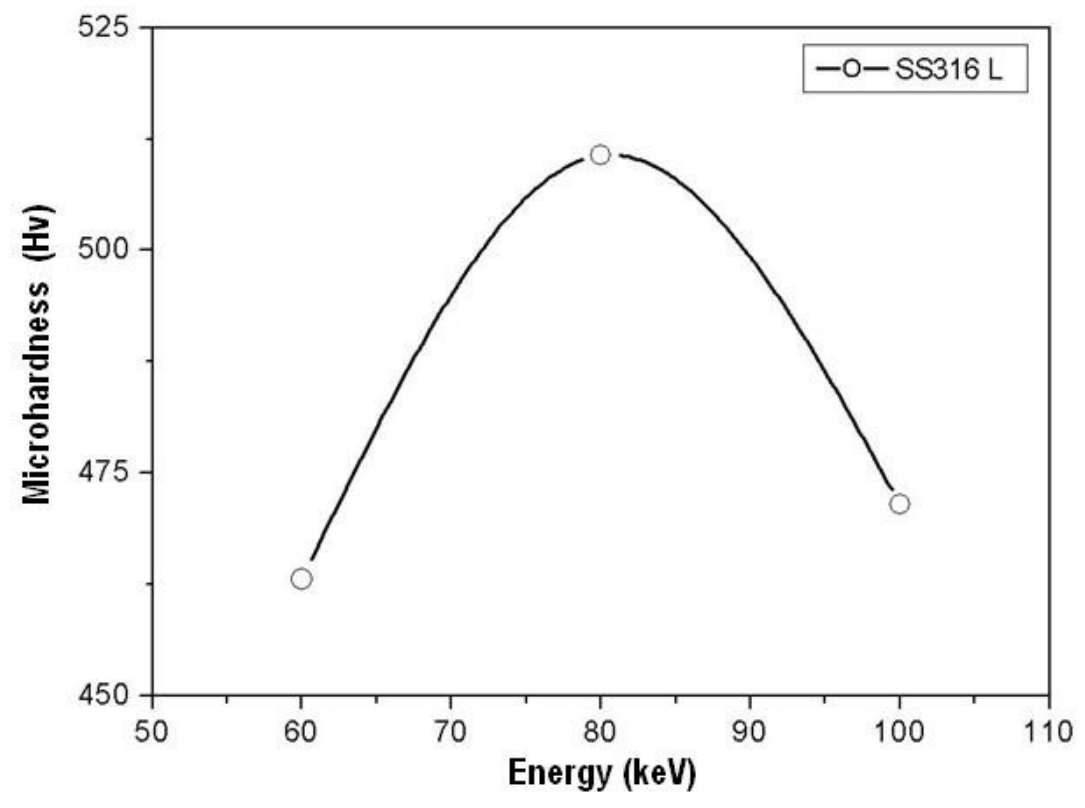

Figure 1. Graph hardness of the ion implanted AISI $316 \mathrm{~L}$ SS samples as a function of ion energy variation on the ion dose of $5 \times 10^{16} \mathrm{ion} / \mathrm{cm}^{2}$

Microstructure and chemical composition of the surface of the samples are analyzed using Scanning Electron Microscopy (SEM) equipped with Energy Dispersive X-ray (EDX). Figure 2 shows the microstructure of the surface of an unimplanted samples, and it can be seen that the surface is smooth and without nitrogen content. Figure 3.(a-c), show the surface microstructure and the chemical composition of the implanted surface at ion energy of 60, 80 and $100 \mathrm{keV}$ respectively. At the ion energy of $60 \mathrm{keV}$ (Figure 3.(a)), it can be seen that the domain boundaries began to appear, but it is not so clear. Nitrogen content is observed in the implanted samples, which indicates that the nitrogen has been implanted into samples. The amount of nitrogen content in the surface of sample is about $6.32 \mathrm{at} \%$. By increasing the ion energy to $80 \mathrm{keV}$ (Figure 3.(b)) and $100 \mathrm{keV}$ (Figure 3.(c)), it seems that the domain boundaries appear more clearly, and the white area on boundaries due to nitride phases are formed. These nitride phases formed are enhance the hardness behavior of the implanted samples ${ }^{(10)}$. It is 
Jurnal Iptek Nuklir Ganendra

Ganendra Journal of Nuclear Science and Technology

Vol. 16 No. 2 Juli 2013: 67-75

confirmed by the morphology of the surfaces of ion implanted samples using XRD techniques as shown in Figure 4.
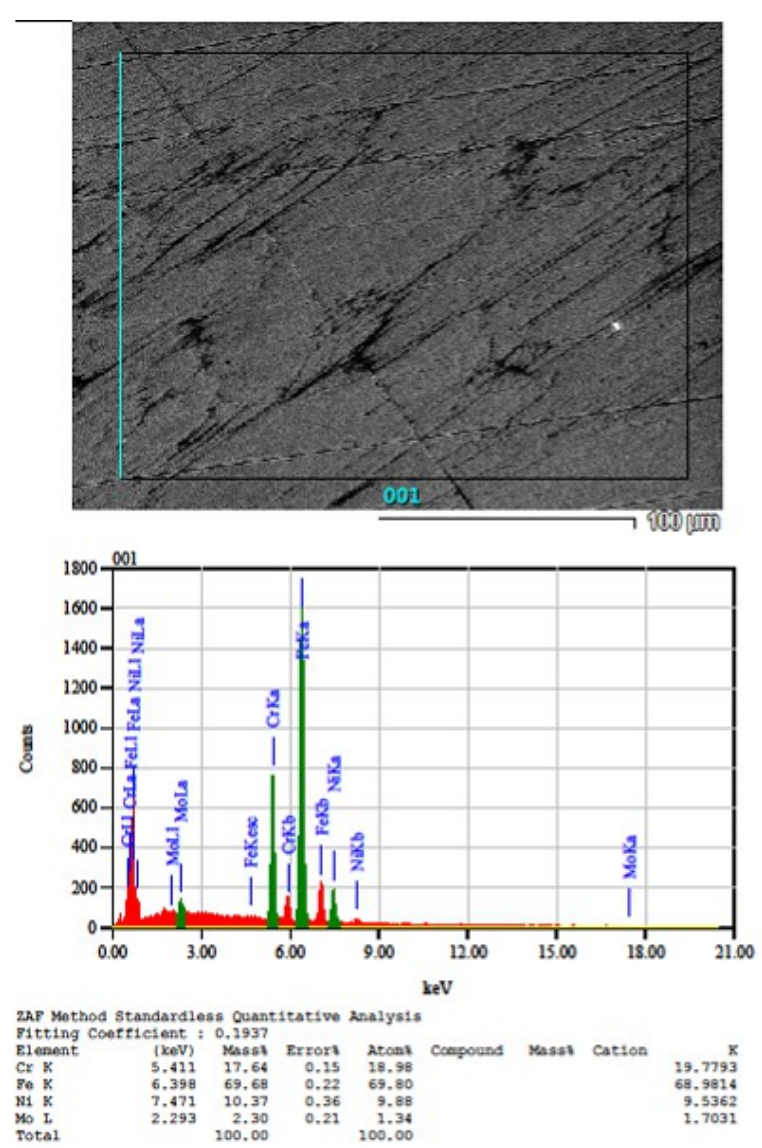

Figure 2. SEM-EDX micrographs of the unimplanted AISI 316L SS samples 
Corrosion Resistance Improvement of AISI 316L Stainless Steel Using Nitrogen Ion Implantation (Sudjatmoko, Lely Susita R.M., Wirjoadi, Bambang Siswanto)
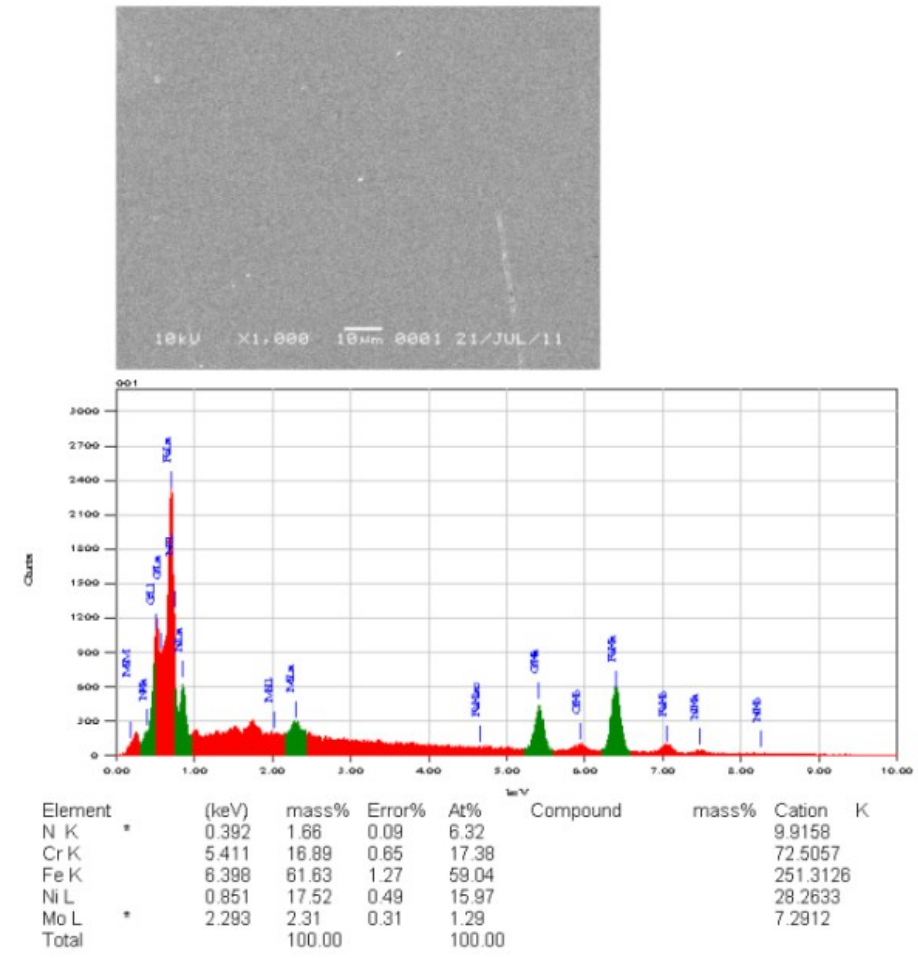

(a)
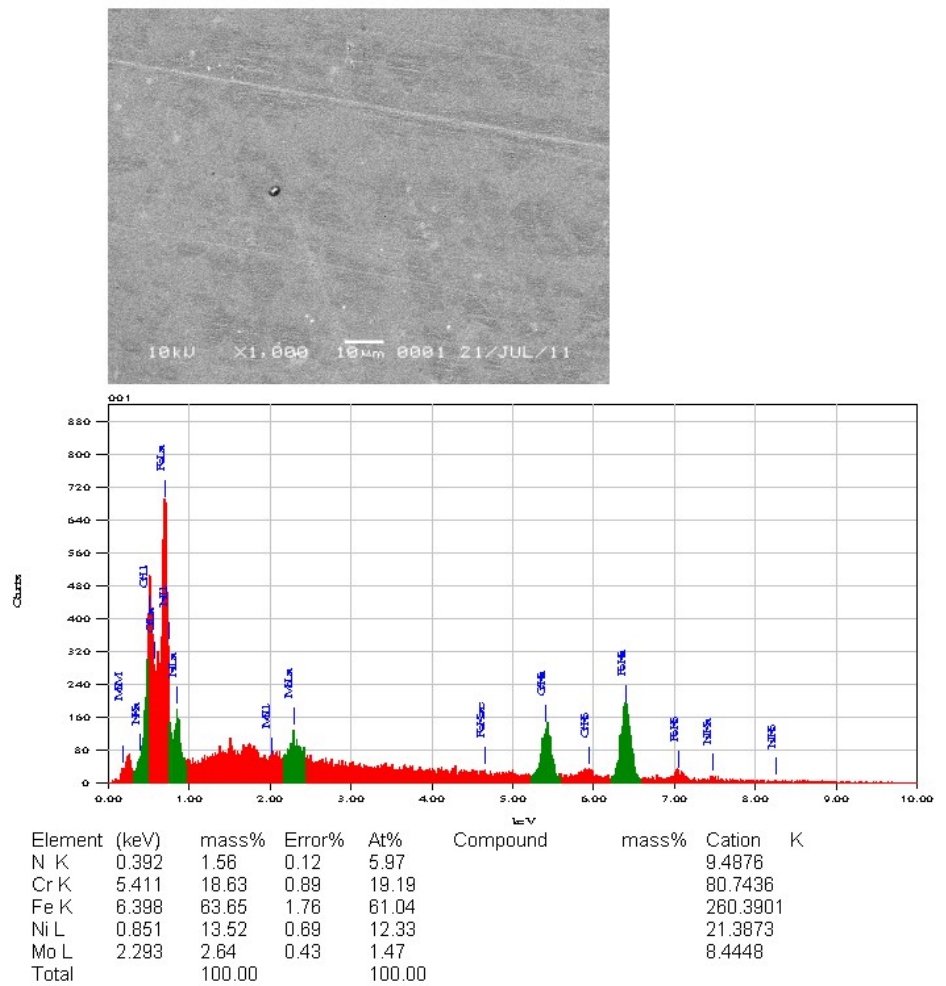

(b) 


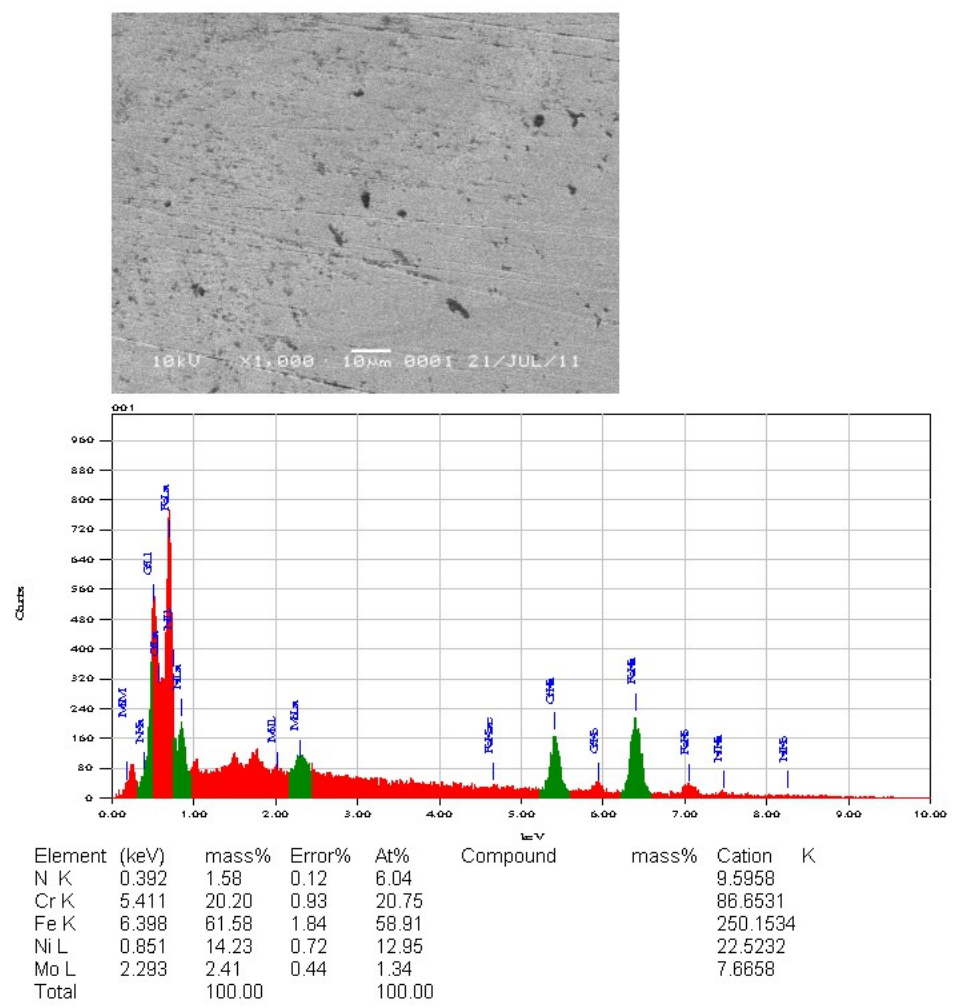

(c)

Figure 3. SEM-EDX micrographs of the ion implanted AISI $316 \mathrm{~L} \mathrm{SS} \mathrm{samples} \mathrm{on} \mathrm{an} \mathrm{ion} \mathrm{dose} \mathrm{of} 5 \times 10^{16} \mathrm{ion} / \mathrm{cm}^{2}$ for variation of ion energy: (a) $60 \mathrm{keV}$, (b) $80 \mathrm{keV}$ and (c) $100 \mathrm{keV}$

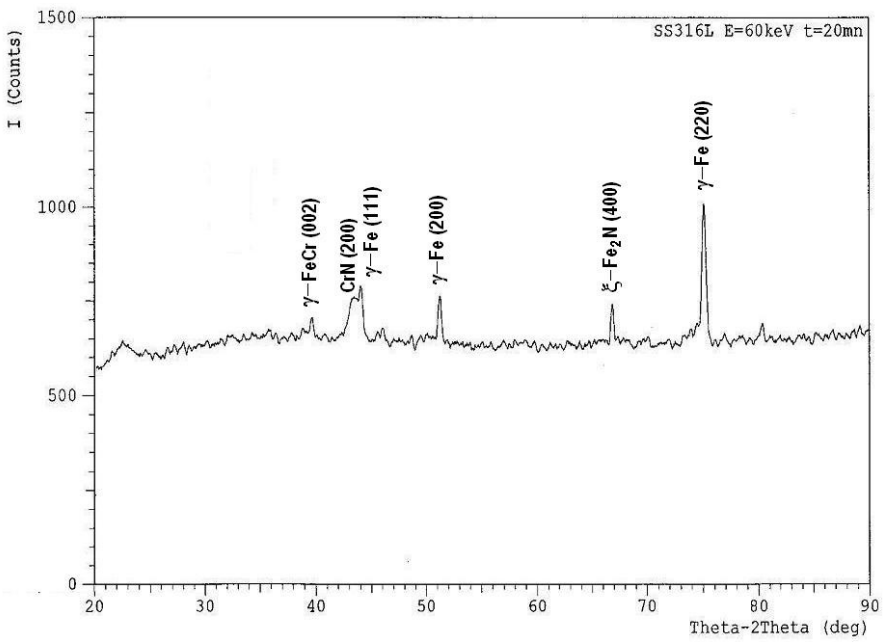

(a) 
Corrosion Resistance Improvement of AISI 316L Stainless Steel Using Nitrogen Ion Implantation (Sudjatmoko, Lely Susita R.M., Wirjoadi, Bambang Siswanto)

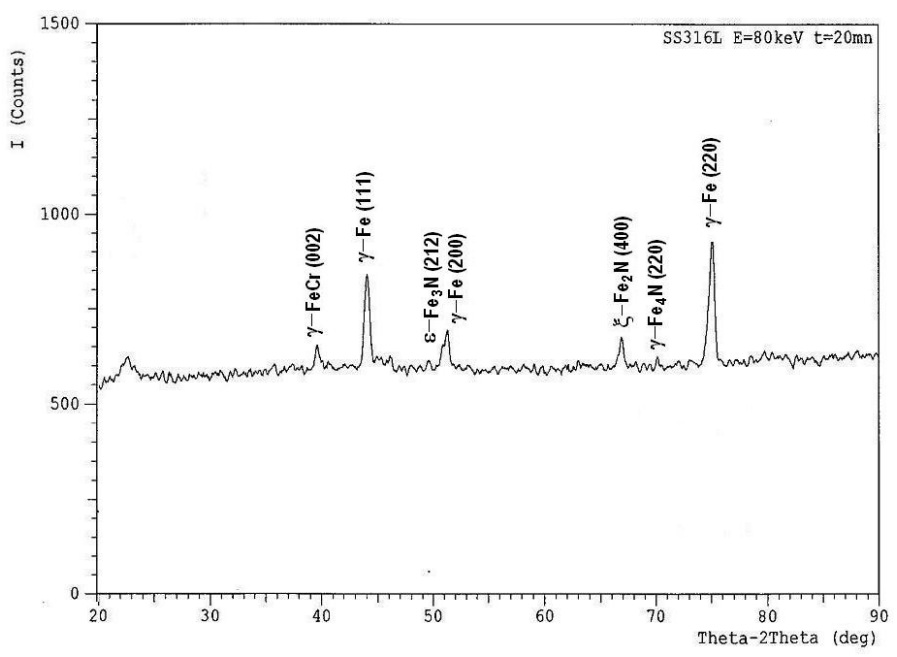

(b)

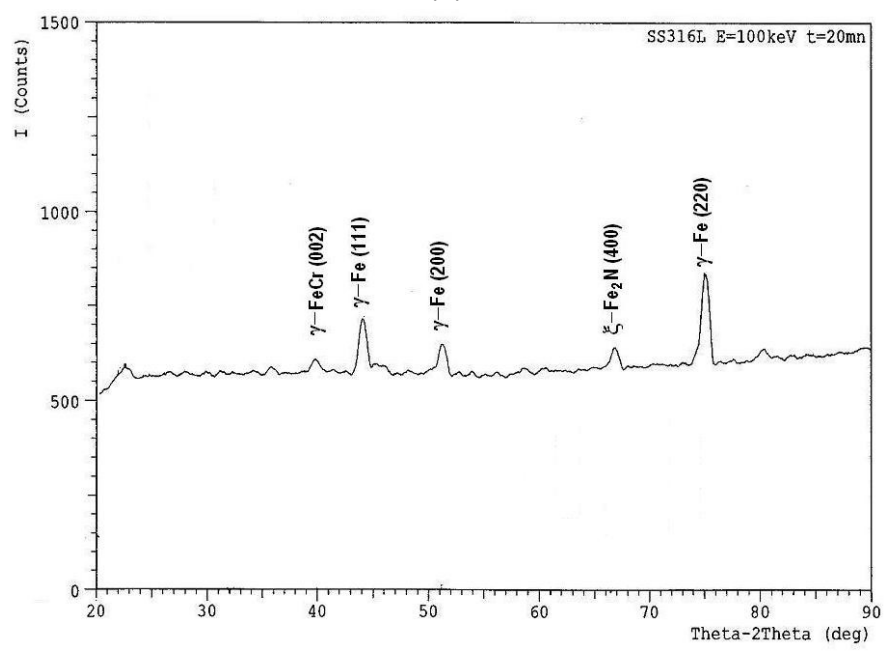

(c)

Figure 4. Diffraction patterns of the ion implanted AISI 316L SS samples on an ion dose of $5 \times 10^{16} \mathrm{ion} / \mathrm{cm}^{2}$ for variation of ion energy: (a) $60 \mathrm{keV}$, (b) $80 \mathrm{keV}$ and (c) $100 \mathrm{keV}$,

The ion implanted samples were analyzed by X-ray diffraction (XRD) with $2 \theta$ range $20^{\circ}-90^{\circ}$. Figure 4.(ac) represents the X-ray diffraction pattern of the ion implanted AISI $316 \mathrm{~L}$ samples on an optimum ion dose of $5 \times$ $10^{16}$ ion $/ \mathrm{cm}^{2}$ for variation of the ion energy of 60,80 and $100 \mathrm{keV}$. From the information of scattering angle, intensity and the distance between the planes on Figure 4, after the data are matched with JCPDS (Joint Committee Powder on Diffraction Standards), the nitride layer formed on the surface of ion implanted AISI 316L SS produces the peaks of $\mathrm{CrN}, \xi-\mathrm{Fe}_{2} \mathrm{~N}, \varepsilon-\mathrm{Fe}_{3} \mathrm{~N}$, and $\gamma^{\prime}-\mathrm{Fe}_{4} \mathrm{~N}$.

Figure 4.(b) shows the diffraction patterns of ion implanted AISI 316L SS samples on the ion energy 80 $\mathrm{keV}$. In contrast to Figure 4.(a), in Figure 4.(b) the CrN peak not observed, but the other peaks appear, i.e. the peaks of $\varepsilon-\mathrm{Fe}_{3} \mathrm{~N}$ and $\gamma^{\prime}-\mathrm{Fe}_{4} \mathrm{~N}$. The peak of $\mathrm{Fe}_{3} \mathrm{~N}(212)$ occurs at an diffraction angle of $50.8^{\circ}$ with the distance between planes is $1.79584 \AA$, and peak of $\mathrm{Fe}_{4} \mathrm{~N}(220)$ at an diffraction angle of $70.0^{\circ}$ with the distance between planes is $1.34198 \AA$. The iron nitride $\gamma^{\prime}-\mathrm{Fe}_{4} \mathrm{~N}$ is the iron-richest stable phase in the binary system iron-nitrogen. This and other binary iron nitride phases such as $\varepsilon-\mathrm{Fe}_{3} \mathrm{~N}$ and $\xi-\mathrm{Fe}_{2} \mathrm{~N}$ have particular impact as hard, corrosion and wear resistant surface layer of iron and steel components ${ }^{(17)}$. While Figure 4.(c) same as Figure 4.(a), except that in Figure 4.(c) peak of $\mathrm{CrN}$ is not observed. The corrosion resistance behavior of these samples are confirmed with the corrosion test results as shown in Figures 5-6. 
In Figure 5.(a-c) shown the potential curve vs. log of the corrosion current density intensity of an implanted AISI 316L SS samples. Corrosion test of the samples carried out by using a potentiostat PGS 201T in Hanks solution, and the corrosion rate are calculated from the current density intensity obtained in Figure 5.(a-c). The corrosion current density measured showed much or little of metal ions dissolved in the electrolyte solution. If the measured current density is large, then many metal ions that dissolve into the electrolyte solution, which indicates that there has been a greater corrosion rate. From the Figure 5.(a-c) it can be seen that the corrosion current densities are 193.42, 159.47 and $281.14 \mu \mathrm{A} / \mathrm{cm}^{2}$ respectively, on ion energy of 60,80 and keV. Based on these data the corrosion current densities obtained from Figure 5.(a-c) it can be made a graph of the corrosion current density as a function of ion energy as shown in Figure 6 . From Figure 6 it can be seen that the nitrogen ion implantation can improve the corrosion resistance of AISI 316 LS, and the optimum corrosion resistance of AISI $316 \mathrm{~L} \mathrm{SS}$ is obtained at the ion dose of $5 \times 10^{16} \mathrm{ion} / \mathrm{cm}^{2}$ and the ion energy of $80 \mathrm{keV}$. These results indicate that the corrosion resistance increased by a factor of 2.6 when compared with the unimplanted samples. Similar results are also obtained by Muthukumaran et al..$^{(6)}$, where they perform ion implantation of nitrogen with the ion energy $100 \mathrm{keV}$ and an ion dose of $1 \times 10^{17} \mathrm{ion} / \mathrm{cm}^{2}$ on the surface of AISI $316 \mathrm{LSS}$. Their results indicated that there was a significant improvement in both corrosion and hardness in the case of implanted samples. Tian et al. (11) also perform nitrogen plasma ion implantation on the surface of magnesium alloy, and they obtain the result that nitrogen plasma ion implantation can effectively improve the corrosion resistance of magnesium alloys under proper conditions.

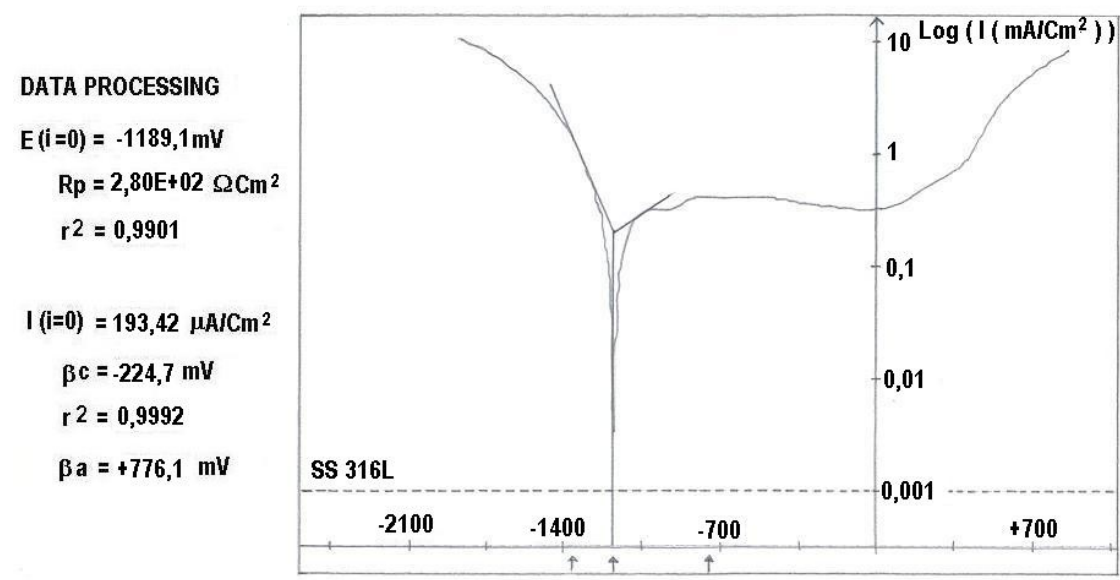

(a)

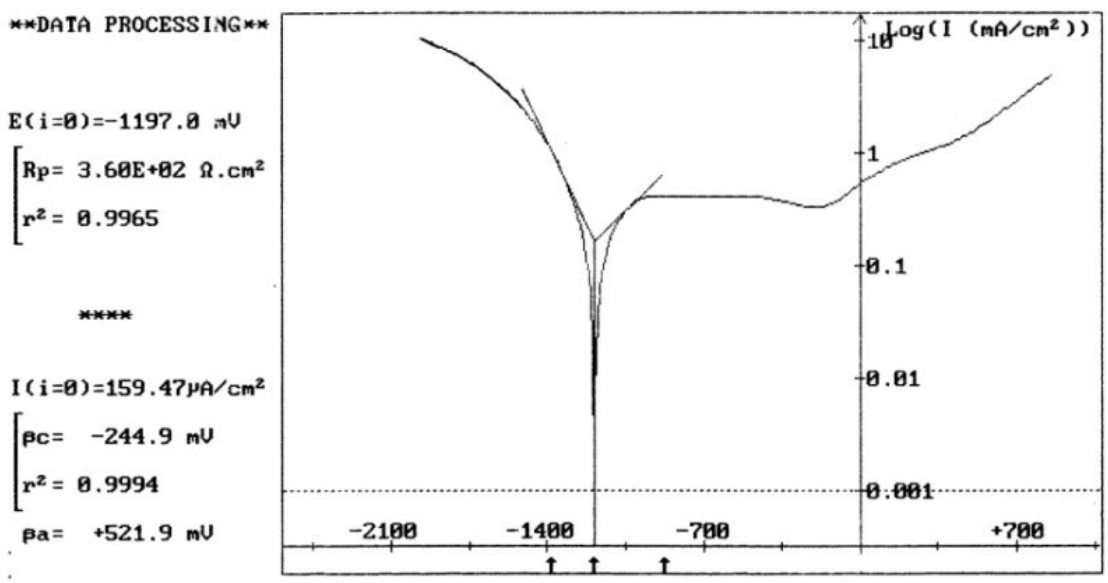

SS 316L ( $t=20 \mathrm{mnt}$; $E=80 \mathrm{KeU}$; $I=180 \mathrm{uA})$ dalam larutan HANKS 
(b)

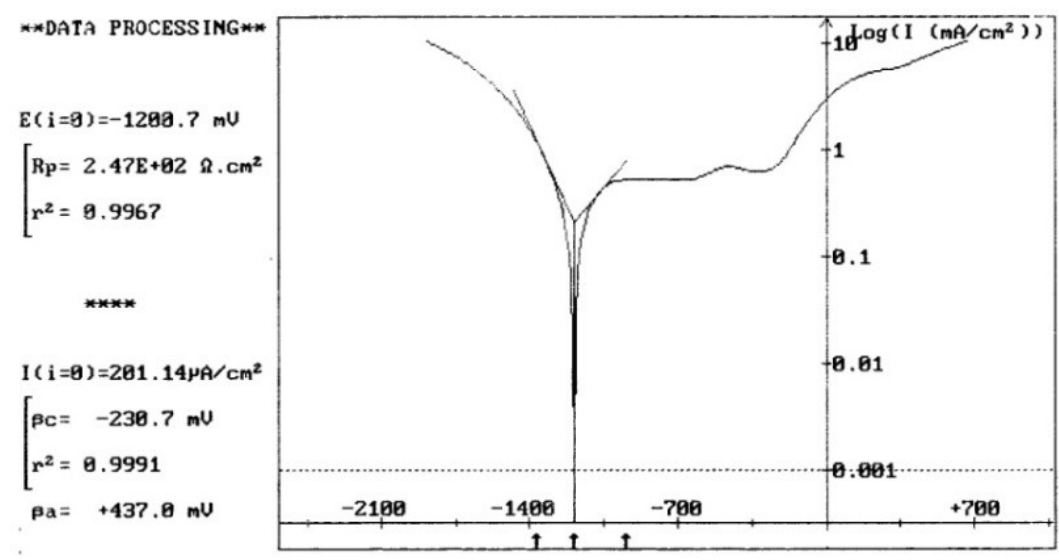

SS 316L ( $t=28$ mnt; $E=190 \mathrm{KeV} ; \mathrm{I}=190 \mathrm{uA}$ ) dalam larutan HANKS

(c)

Figure 5. Potential curve vs. log of corrosion current densities intensity of implanted AISI $316 \mathrm{~L}$ SS samples with an ion dose of $5 \times 10^{16} \mathrm{ion} / \mathrm{cm}^{2}$ for a variation of ion energy: (a) $60 \mathrm{keV}$, (b) $80 \mathrm{keV}$ and (c) $100 \mathrm{keV}$

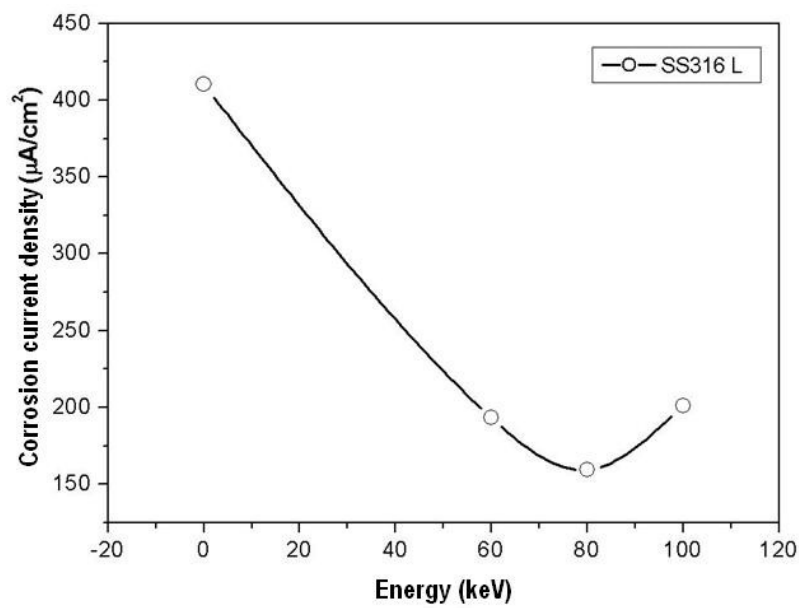

Figure 6. Graph of corrosion current density vs the variation of nitrogen ion energy for implanted AISI 316L SS samples on an ion dose of $5 \times 10^{16} \mathrm{ion} / \mathrm{cm}^{2}$.

\section{CONCLUSION}

Based on the research and discussion as described above can be concluded as follows. The nitrogen ion implantation can effectively improve the hardness and the corrosion resistance of AISI 316L SS. The surface hardness for implanted samples are higher than that of the unimplanted sample by a factor of 1.3. From the analytical technique using SEM and EDX it was found that the domain boundaries appear on the surface layer of implanted AISI 316L SS samples, and the white areas on boundaries due to nitride phases were formed. The nitride phases which formed enhance the hardness behavior of the implanted samples. XRD diffraction patterns were used to analyze the surface morphology of implanted AISI 316L SS, and based on the XRD diffraction patterns observed peaks of $\mathrm{Fe}_{2} \mathrm{~N}, \mathrm{Fe}_{3} \mathrm{~N}$ and $\mathrm{Fe}_{4} \mathrm{~N}$. Iron nitride $\gamma{ }^{\prime}-\mathrm{Fe}_{4} \mathrm{~N}$ is the iron-richest stable phase in the binary system iron-nitrogen. This iron nitride $\gamma^{\prime}-\mathrm{Fe}_{4} \mathrm{~N}$ and other binary iron nitride phases such as $\varepsilon-\mathrm{Fe}_{3} \mathrm{~N}$ and $\xi$ $\mathrm{Fe}_{2} \mathrm{~N}$ have special properties such as very hard, corrosion and wear resistant surface layer of iron and steel components. From the evaluation by using a potentiostat PGS 201T showed that there was a significant improvement in the corrosion resistance in the case of nitrogen implanted samples. 
Jurnal Iptek Nuklir Ganendra

Ganendra Journal of Nuclear Science and Technology

Vol. 16 No. 2 Juli 2013: 67-75

\section{ACKNOWLEDGEMENTS}

The research activities are fully funded by the Incentive Program of Increased Ability of Researchers and Engineers (PIPKPP) 2011, the Ministry of Research and Technology. Therefore, on this occasion the author thank to BATAN and the Ministry of Research and Technology that have funded our research activity, so this research can be implemented.

\section{REFERENCES}

M.K. LEI, X.M. ZHU, Surface \& Coatings Technology, 193 (2005) 22-28

JUN WANG, JI XIONG, QIAN PENG, HONGYUAN FAN, YING WANG, GUIJING LI and BAOLUO SHEN, Materials Characterization, 60 (2009) 197-203

S. NAGARAJAN, N. RAJENDRAN, Corrosion Science, 51 (2009) 217-224

URS I. THOMANN, PETER J. UGGOWITZER, Wear, 239 (2000) 48-58

A. MOTALEBI, M. NASR-ESFAHANI, R. ALI, M. POURRIAHI, Progress in Natural Science: Materials International, 22(5), (2012) 392-400

V. MUTHUKUMARAN, V. SELLADURAI, A.R. REGHURAJ, M. SENTHILKUMAR, Acta Mechanica Slovaca, 14(1), (2010) 80-87

A. ZIEBOWICZ, J. MARCINIAK, Journal of Achievements in Materials and Manufacturing Engineering, Volume 18, Issue 1-2 (2006) 199-202

LIANG CHENG HAO, GUO LIANG, CHEN WAN, LIU JING XIAO, Trans. Nonferrous Met. Soc. China, Vol. 13, No.2 (2003) 398-401

A. DURAN, A. CONDE, A. GOMEZ COEDO, T. DORADO, C. GARCIA and S. CERE, Journal of Materials Chemistry, 14 (2004) 2282-2290

O. ÖZTÜRK, Nuclear Instruments and Methods in Physics Research B, 267 (2009) 1526-1530

X.B. TIAN, C.B. WEI, S.Q. YANG, RICKY K.Y. FU, and PAUL K. CHU, Surface \& Coatings Technology 198 (2005) 454-458

J.XU, C. ZHUO, J. TAO, S. JIANG, and L. LIU, Journal of Physics D: Applied Physics, 42 (2009) 1-12

J. PAYAMARA, and M. GHORANNEVISS, International Journal of ChemTech Research, Vol. 3, No. 1 (2011) 309-313

S. HIROMOTO, K. KANO, Y. SUZUKI, K. ASAMI, A. CHIBA and T. HANAWA, Materials Transactions, Vol. 46, No. 7 (2005) 1627-1632

MUDALI, U.K., SRIDHAR, T.M., and RAJ, B., Sadhana, 28, 3-4, (2003) 601-637

B.R. LANNING, R. WEI, Surface and Coatings Technology, Volume 186, Issues 1-2, (2004) $314-319$

J.CWIEK, M. BACZYNSKA, Archives of Materials Science and Engineering, Volume 43, Issues 1, (2010) 30-41 